Journal of Social Sciences 7 (4): 619-626, 2011

ISSN 1549-3652

(C) 2011 Science Publications

\title{
Rural Students' Skills and Attitudes Towards Information and Communication Technology
}

\author{
${ }^{1}$ Hairulliza Mohamad Judi, ${ }^{1}$ Hazilah Mohd Amin, \\ ${ }^{1}$ Nor Azan Mat Zin and ${ }^{2}$ Rodziah Latih \\ ${ }^{1}$ School of Information Technology, \\ ${ }^{2}$ School of Computer Science \\ Faculty of Information Science and Technology, \\ Universiti Kebangsaan Malaysia, 43600 UKM Bangi, Malaysia
}

\begin{abstract}
Problem statement: Despite various initiatives and programmes by the government to incorporate ICT in education, not much research has been done to evaluate the achievement of these initiatives and programmes, including ICT proficiency among students. This study fills in the gap of lack of current information pertaining to the Malaysian secondary school students' ICT competencies, knowledge on internet and attitudes toward computer technology. Approach: Data for this study has been gathered from a survey on 585 students in Sekolah Menengah Kebangsaan Tengku Temenggung Ahmad (SMKTTA) in the rural district of Kundang Ulu, Johore. The specific area has been selected by Universiti Kebangsaan Malaysia under one of its community service projects.The instrument used was a questionnaire comprised of demographic variables and three other sub-scales. The sub-scales are software and hardware usage; motivation for self study and ICT usage competency and Internet usage and safety awareness. Results: Results show that generally, students have moderately positive attitudes toward ICT, have low to moderate level of ICT competencies and have limited knowledge on internet. Conclusion: Findings from this study have implications to the approach of teaching and learning of ICT subjects, their evaluation and assessment and future initiative related to ICT education and infrastructure development towards creating a well-connected society. It is recommended that schools provide enough facilities for students' hands-on experiences. Teachers should incorporate productive computing activities in their teaching such as using spreadsheet, database and programming, besides purposive web searching. Rural internet centres should also be established. Evaluation, monitoring and maintainance of ICT programs is a must to ensure their effectiveness and efficiency. The utmost end result would be the emergence of more ICT proficient personnel who will contribute to the development of the country.
\end{abstract}

Keywords: Computer literacy, proficient personnel, rural students, limited knowledge, computer education, secondary school, Information and Communication Technology (ICT)

\section{INTRODUCTION}

Information and Communication Technology (ICT) skills play an important role in developing a nation. ICT has been regarded as an important tool to leverage economy and society, thus mastering basic skills and concepts of ICT become one of the core parts in education, besides reading, writing and numeracy. ICT skills are necessary prerequisites for information literacy and life-long learning. Students who possess ICT skills will be able to serve as worthy citizens in their communities and understand how society operates in information age (Burniske, 2001). On the other hand, students who do not have these skills are likely to encounter more challenges with the increased workplace demands for computer literate employees (Hindi et al., 2002). The computer skills that are required by employers are download/upload files, web programming, designing and querying databases, install/upgrade softwares, developing and editing databases and word processing.

Among the required knowledge and skills for those who want to enter into the competitive employment market are proficiency with computer technology. Students who did not have access to computers and the Internet technology would potentially miss out the $70 \%$

Corresponding Author: Hairulliza Mohamad Judi, School of Information Technology, Faculty of Information Sciences and Technology, Universiti Kebangsaan Malaysia, 43600 UKM Bangi, Malaysia 


\section{J. Social Sci., 7 (4): 619-626, 2011}

of jobs which require moderate or high level computer knowledge and eventually ended up in the $10 \%$ lowpaying jobs that do not require technical knowledge (Tella and Mutula, 2008).

The Malaysian government is committed to the use of ICT to boost economy and to become a developed nation by 2020 . In striving to achieve this status, the government has outlined several important strategies to improve human resources in ICT which involve longterm planning to upgrade the quality of current education system in primary and secondary schools. Among important element in this planning is the establishment of Smart Schools. In 1999, a total of 88 schools were chosen to become smart schools which showcased the state-of-the-art teaching and learning using technology effectively and efficiently. According to the master plan, all 10,000 schools in Malaysia should become smart schools by 2010 Multimedia Development Corporation, 2005.

Malaysia's Ministry of Education (MoE) is equipping teachers with computer facilities such as notebooks, with the aim of increasing computer literacy and enhancing the learning experience for both students and teachers. A total of 100,000 notebook computers and 80,000 Liquid Crystal Display (LCD) projectors plus other peripherals and teaching courseware were provided for Malaysian Science, Mathematics and English language teachers. Moreover, the MoE plans to have all schools set up with wireless Local Area Networks (LANs) by 2007 (Kumar et al., 2008a). The $\mathrm{MoE}$ is also providing each school with computer laboratories, as mentioned in the Smart School Program. In addition, in the Computerization of Schools Program, the Ministry will provide between 20 to 40 computers to schools that have 600-1,200 students (Kumar et al., 2008b). A website known as MySchoolNet, was also set up by the MoE to help teachers and students access educational information readily and thus encourages interactive communication between Malaysian school children and students from other countries (Idrus and Atan, 2004).

Despite thevarious initiatives by the government to incorporate ICT in education, not much research has been done to evaluate the achievement of these initiatives and programmes, including ICT proficiency among students. It is expected that students are equally ICT literate in both urban and rural areas as there is no obvious evidence of digital divide between students in urban and rural areas exist in Malaysia (Yasin, 2002). Students in urban area seems to be more fortunate because they have more opportunity to access ICT facilities either by using their own computer or cybercafé in their neighbourhood. However, for students in rural areas, they depend mostly on computer facilities provided by their schools. Therefore, most schools in rural areas need help to run more ICT programmes and facilities to enhance their students' ICT skills.

This study reports the results based on data gathered from students in Sekolah Menengah Kebangsaan Tengku Temenggung Ahmad (SMKTTA), located in a rural area in Malaysia i.e., Kundang Ulu, regarding this issue. Kundang Ulu area has been selected by Universiti Kebangsaan Malaysia under one of its community service projects. A comprehensive plan for this community development looked at various aspects such as ICT literacy development and enhancement, health promotion and disease prevention and academic excellence. The researchers are members in the ICT project team. Various activities were implemented by the team such as providing training on hardware maintenance (Hairulliza et al., 2010). As one of the research objectives in the project, requirement analysis was conducted to identify the problems or gaps in ICT literacy among students in the area. This study seeks to shed some light with regard to the following questions:

- What are the backgrounds of students in rural area regarding ICT skills?

- What are the attitudes of the students in rural area concerning the use of ICT?

- What are the skills of these students concerning the use of computer technologies?

- What is the internet knowledge level of the students?

This study aims to discuss about ICT skills and attitude towards ICT, explain the research procedure undertaken in the project, present the results and suggest recommendations based on the findings.

\section{Background of the study:}

ICT skills: Information technology refers to method, tool, content and software involved in the unlimited process of developing, gathering, processing, managing, disseminating and recording of information.

Communication is a process of sending, receiving and sharing of means between the related parties. ICT includes tools, software, contents, applications and products that posses, bring together, promote, expose and record message or knowledge that can be accessed and used at anytime. Computer and internet are the tools that are most related to ICT. Among ICT tools and service include internet-based communication and transaction systems, mobile devices, computer integrated telephony, groupware, workflow and multimedia. 
Table 1 ICT Competency from previous studies (Teck and Lai, 2011) (Zuhari et al., 2009) (Ariffin, 2005)

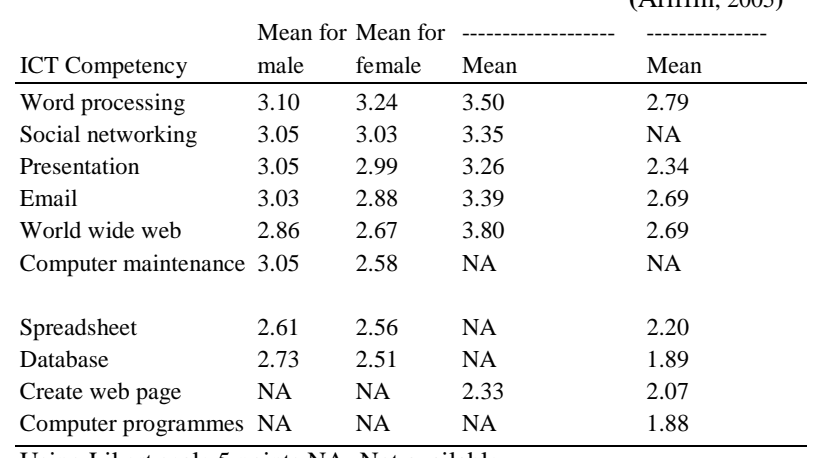

Using Likert scale 5 points NA- Not available

Skills are related to the ability or proficiency that is acquired or developed through training or experience. In order to complete assignments-from essay writing, to presentations, to analysis of data; students will need to develop skills in accessing and using the appropriate software available to support these activities. In this context, skills aspects refer to ability among students in using ICT which they learned in ICT programme such as skills in using Microsoft Office and surfing internet. Skills aspects focus on the ability among individual to apply and arrange their learning in a more creative and innovative way. Students, who are competent in ICT skills will be able to capture, process, store and transfer information that will enable them to focus on information content, communication, analysis, searching and evaluation (Bidgoli, 2004).

Various local studies have been done to measure ICT skills among students. While Teck and Lai (2011) and Zuhari et al. (2009) studied ICT competencies of students at college level in urban and rural area respectively, Ariffin, (2005) conducted a survey to evaluate secondary school students in a rural area in Kubang Pasu, Kedah. Table 1 presents a comparison of ICT competency level, conducted by these three researchers. In (Teck and Lai, 2011), ICT competencies among pre-university students were evaluated based on the criteria as follows: word processing, presentations, spreadsheets, World Wide Web, electronic mail, database, social networking, computer maintenance and utility. The results indicate that in general the levels of ICT competencies for pre-university students (age 18 and 19 years old) in Malaysia are still low. Word processing has the highest level of ICT competencies. The male students have the lowest level of spreadsheet competency while their female counterparts have the lowest level of database competency.

Zuhari et al. (2009) studied ICT skills among 108 students in three rural community colleges. Her findings show that community college students have high score on information search through using search engine such as Yahoo and Google. Both search engines are popular among students (Kaur and Siok, 2002). Although students are good at information retrieval skills using the Internet, their internet application skills such as send and receive email, file attachments, email groups, chat groups and manage files and folders on a computer network are still at a moderate level. Word processing skill is also at a moderate level. Students have low level skill in creating, modifying and maintaining website. This is because they do not have the opportunity to learn how to create websites. Overall ICT competency for community college students in rural areas is moderate.

Ariffin (2005) conducted a study of 554 Form Four students (average of 16 years old) in a rural area in Kubang Pasu, Kedah. Her research focused on ICT competencies in writing documents, preparing spreadsheets, scanning documents or images, editing images, preparing slides, sending email messages, creating web pages, uploading documents, searching information on the web, using software for computer assisted learning, printing documents, creating databases and writing computer programs. Generally, the results showed that students have low level of ICT skills. Most of the students had slightly better skills in word-processing or web-based tasks such as emailing and searching for information on the web.

Attitudes towards ICT: Not only students' ICT skills is important, their attitude towards ICT do matter. If students are to adopt computer technologies, they must have the right kind of attitudes towards computers (Tengku, 2005; Hassan et al., 2011). Researchers have investigated the relationship between computer attitudes and computer adoption. Students, who perceived the usefulness of computer and feel confident in using it, appear to be more positive in their attitudes toward ICT, thus tend to use computer more (Noiwan et al., 2005). In real world, motivation is highly valued because of its consequences where it mobilizes others to act (Ryan and Deci, 2000). The more the learning is intrinsically motivating, the more students will seek the knowledge for its own sake (Schweinle et al., 2006). When individuals learn for the sake of intrinsically motivating purposes, there will be greater persistency and consequently, this facilitates learning process in the long term (Vansteenkiste et al., 2004). Therefore, there is a need to tap into students' intrinsic motivation gained through ICT literacy class as an indicator whether students do enjoy learning the subject in school and perceived themselves as better off than previously.

In general, there are four constructs in measuring attitude towards ICT, which are: (i) computer anxiety; 


\section{J. Social Sci., 7 (4): 619-626, 2011}

(ii) computer confidence; iii) computer liking; and (iv) computer usefulness (Ariffin, 2005). However, there is no consensus among researchers in measuring the attitude. Another study employed three constructs i.e. (i) cognitive; (ii) affective; and (iii) psychomotor (Zuhari et al., 2009).

A survey on attitude towards ICT among secondary school students in rural areas showed that these students have positive attitudes towards ICT but low level in ICT skills (Ariffin, 2005). These students showed a moderate level of confidence and attitude, but high level of perception toward computer usefulness. Similar study on computer literacy level of undergraduate students in Universiti Kebangsaan Malaysia showed that there is a significant difference in computer literacy level between male and female students; male students had greater computer experience and use computer more frequently and have a higher computer ability. They had greater self-perceived control and higher programming skills and better ability in computer repair and maintenance than females. The study also found that computer experience and computer ownership affect computer literacy level (Zin et al., 2000). In related study, Othman and Latih (2006) found no correlation between prior experience in computer and success. Even though male students spend significantly more time playing computer games, programming and hacking, these activities do not result in outpacing female students, which implies the amount of time spent at the computer is not a measure of how well one performs academically.

Found that overall students in schools and in higher learning institutions, especially the Malays, are positive and confident to face the emergence of computers and their use. They strongly agreed that ICT skills help them to learn, to enjoy learning, to find jobs, to do work efficiently and save time. Malay students show positive attitude towards ICT than non-Malay students. Students from urban area appear to be more positive in their attitude towards ICT than rural students. Results from (Zuhari et al., 2009) show that students scored high in all cognitive, affective and psychomotor constructs. These findings imply that the studied community college students have high level of perception toward computer usefulness, enjoy using ICT and feel motivated to use ICT in their work.

\section{MATERIALS AND METHODS}

This study was carried out to investigate the level of computer literacy level among the students of Kundang Ulu, a rural area in Johore, a state south of Malaysian peninsular. Johore is a much more developed part of the country due to its proximity to Singapore.
The people in Johore are more modern and literate, hence the general expectation is that they are more ICT literate compared to the rest of the Malaysians. The data were gathered in a case study of ICT literacy enhancement program carried out at a high school in Kundang Ulu. The instrument used was a questionnaire comprised of demographic variables and three other components or sub-scales. The sub-scales are software and hardware usage; motivation for self study and ICT usage competency and Internet usage and safety awareness. Most items in the questionnaire were modified from previous researches, such as (Hindi et al., 2002). The internal reliability calculated for the scale is 0.94 and sub-scales reliabilities are also high at $\alpha=$ 0.930 for sub-scale software and hardware usage, $\alpha=$ 0.928 for sub-scale motivation for self study and ICT usage competency and $\alpha=0.829$ for sub-scale Internet usage and safety Awareness. Demographic variables include gender, age, computer experience (number of years of computer use: (never use, 1, 1-4 and 5-10 years), computer ability, computer ownership and frequency of computer usage per week $(<1,3-5,5-7$ and $>7 \mathrm{~h}$ per week). A total of 585 questionnaires were collected. Data were analyzed using SPSS version 18.0.

\section{RESULTS}

The total sample in this survey is 585 participants. The participants' gender is almost equal, $43 \%$ male and $57 \%$ female.

Table 2 shows the results for students' perception on ICT self learning and ICT as learning tool. This component reflects students' attitude towards ICT. The table presents the mean and standard deviation scores of items in this component and the motivation level. Two items show means close to high level category. These are interest of using computer when there is an opportunity and interested to study computers.

Table 3 presents the participants' perception of their ICT skills, particularly on hardware and software. The items represent the first component of ICT literacy, the skills in ICT hardware and software. There are altogether 15 items in the component that are evaluated using a Likert scale of 1 to 5. For this component, the ICT skills of participants are found to be in moderate or weak level. Participants show higher score in certain items, i.e., using Internet to find information and entertainment, followed by identifying the hardware and using Microsoft Word. Their skills in five items were categorised as weak. These items involved using antivirus, multimedia, email, authoring application and Microsoft Excel software. 
Table 2: Attitude towards ICT

\begin{tabular}{|c|c|c|c|}
\hline Item & Mean $^{\mathrm{a}}$ & Standard deviation & Level \\
\hline Using the computer when there is opportunity & 3.64 & 1.231 & Moderate \\
\hline Interested in studying computer & 3.61 & 1.221 & Moderate \\
\hline Computer skills are very important for students & 3.58 & 1.210 & Moderate \\
\hline Computers make teaching and learning more interesting & 3.52 & 1.212 & Moderate \\
\hline Computers save time to work & 3.39 & 1.225 & Moderate \\
\hline Computers help in many ways, including calculating & 3.38 & 1.184 & Moderate \\
\hline Enjoy talking about computers and its technology & 3.36 & 1.238 & Moderate \\
\hline Always wanted to know about the latest in computer & 3.36 & 1.238 & Moderate \\
\hline Computers make teaching and learning effective & 3.24 & 1.156 & Moderate \\
\hline Prefer to work with the help of computers over manual & 3.17 & 1.174 & Moderate \\
\hline Seek help in resolving computer problems & 3.06 & 1.049 & Moderate \\
\hline Using computer application is as easy as other electronic equipment & 3.04 & 1.069 & Moderate \\
\hline Using the latest hardware is exciting & 3.01 & 1.053 & Moderate \\
\hline Excited in trying out new software & 2.95 & 1.117 & Moderate \\
\hline
\end{tabular}

${ }^{\mathrm{a}}$ : using Likert scale 1 = Very weak, $2=$ Weak, 3 = Moderate, $4=$ Skilful , 5= Very skilful

Table 3: ICT skills on hardware and software

\begin{tabular}{|c|c|c|c|}
\hline Item & Mean $^{\mathrm{a}}$ & Standard deviation & Level \\
\hline Information search using internet & 2.95 & 1.252 & Moderate \\
\hline Use of Internet for entertainment & 2.93 & 1.238 & Moderate \\
\hline Identify hardware & 2.83 & 1.217 & Moderate \\
\hline Using Microsoft Word & 2.70 & 1.169 & Moderate \\
\hline Using Microsoft Powerpoint & 2.56 & 1.092 & Moderate \\
\hline Using Bluetooth & 2.53 & 1.254 & Moderate \\
\hline Using Interactive social website & 2.47 & 1.217 & Moderate \\
\hline Using Chat applications such as Yahoo Messenger & 2.42 & 1.140 & Moderate \\
\hline Transferring files from computer to mobile phone & 2.39 & 1.277 & Moderate \\
\hline Knowing the function of hardware & 2.35 & 1.030 & Moderate \\
\hline Using Microsoft Excel & 2.33 & 0.961 & Weak \\
\hline Using email application & 2.25 & 1.060 & Weak \\
\hline Using authoring software such as Authorware & 2.09 & 0.970 & Weak \\
\hline Using multimedia application such as Dreamweaver & 2.08 & 0.959 & Weak \\
\hline Using anti-virus software such as Norton & 2.03 & 0.994 & Weak \\
\hline
\end{tabular}

${ }^{a}$ : using Likert scale 1=Very Weak, 2 = Weak, 3= Moderate, 4=Skilful , 5= Very skilful

Table 4: Knowledge on internet

\begin{tabular}{lll}
\hline & Item (\%) & Response (\%) \\
\hline $\begin{array}{l}\text { Giving real information in } \\
\text { internet transaction }\end{array}$ & Yes (65.5) & No (34.5) \\
$\begin{array}{l}\text { Knowing ".edu" } \\
\text { Knowing ".gov" }\end{array}$ & Yes (30.9) & No (69.1) \\
Knowing “.org" & Yes (29.7) & No (70.3) \\
Knowing search engine & Yes (22.1) & No (77.9) \\
Knowing service provider & Yes (12.5) & No (76.9) \\
Knowing “.com" & Yes (1.9) & No (87.5) \\
Knowing URL & Yes (0) & No (100) \\
\hline
\end{tabular}

Table 4 presents the results of the students' knowledge on ICT application including internet and its usage. Internet is among the most popular ICT applications, therefore knowledge in internet is one indicator of knowledge in ICT. Internet should be an important component in ICT literacy (Hindi et al., 2002). Students were evaluated if they know the right answer related to internet usage. The results show that $65.5 \%$ of students give real information in the internet. It means that $34.5 \%$ of them are aware about the danger of disclosing the correct information when surfing. Less than half of students gave the right answer to indicate they know the meaning of important domains in URL: Edu (30.9\%), gov (29.7\%), org(22.1), $\operatorname{com}(1.9 \%)$. $23.1 \%$ of students were able to give examples of search engine. They gave various answers such as Google, Yahoo and Bing. $12.5 \%$ of students know internet service provider and were able to name the operator. None of the students give correct answer to the full name of URL $(0 \%)$. The results show that they are not familiar with internet's common term.

\section{DISCUSSION}

There are a few important findings from this survey, which will be discussed according to the research questions. First, regarding the background of students in rural area in using ICT. The results show that only a small percentage of students (20\%) own computers at home. Five percent of these students never use computer in their life. Majority of the students $(72.5 \%)$ spend less than an hour in a week on computer. These results are consistent with Yassin (2002) who found that only small percentage of students in rural areas own computers. 


\section{J. Social Sci., 7 (4): 619-626, 2011}

Second, the perception of students in the studied rural area i.e. Kundang Ulu on ICT. This component reflects students' attitude towards ICT especially in the teaching and learning environment. The results show that the overall motivation level of these students to use ICT is moderate. This is justified by the mean score of all items that fall into moderate category. However, there are some items that showed higher score than the rest. Among the items with highest mean score (close to high level in our classification) are related to the interest of using computer, given the facility is available and keen to learn computers. The interest of using computers among these students are considered good, taking into consideration the disadvantage of their geographical location and not having computer.

Besides interest, students' awareness is another important component in their attitude towards ICT. This is related to their perception on the use of ICT as teaching and learning tools. These students have moderate confidence that computer may help them in teaching and learning process. They believed that computer could make teaching and learning more interesting and effective and also help them in tedious calculation work. Affect is the next important components. These students say that they enjoy talking about computers and ICT and always wanted to know about the latest in computer. The ability of students to enjoy using this facility seems to be hindered by the difficulty and effort needed in learning to use them. In their progress of learning ICT, these students may find some difficulty in resolving computer problems and require some help from others, as well as when exploring new hardware and software.

The difficulty that these students have experienced in using ICT may imply the level of knowledge that they have. This is related to the third aspect covered in this study which was intended to evaluate how these students perceived their ICT skills. The results show that these students perceive their ICT skills as moderate or low. In general, they think that they do better in using Internet to find information and entertainment, in identifying hardware and in using Microsoft Word. Whereas, their skills in using antivirus, multimedia, email, authoring application and Microsoft Excel are perceived as weak.

The fourth aspect evaluated in this survey is participants' internet knowledge. The evaluation applies various items that require correct answers from them to get the score. The results show that these students have limited knowledge on internet. It is not surprising that this group of students from rural area obtained low scores in this knowledge. The knowledge is very much contributed by the activities that these students spend the most time. The low score is related to the findings from demographic factors. Very few students have their own computer at home, majority spend less than one hour a week on computers. The results also showed that only $35 \%$ participants were aware of the danger of always giving their private information when using internet. These students require exposure on ethics in using ICT. They require some guideline to apply the technology in safe environment. Hindi et al. (2002) suggested that this topic should not be overlooked as software piracy and internet scams are pertinent realities faced by users. Such exposure would increase their confidence and skills in using ICT.

From these three components, it appears that students' attitude towards ICT is considered moderate; their perceived ICT skills are in weak to moderate level, whereas their internet knowledge is low. It seems that these components have strong connection among them as suggested by (Noiwan et al., 2005; Ryan and Deci, 2000; Schweinle et al., 2006). These students may have limited opportunity in using ICT since only small percentage among them owns computers at home and majority of them spend little time on computer. These factors contribute to their confidence in using ICT and perceived usefulness of ICT in life. Consequently, their attitude towards ICT appears to be moderate.

There are many implications from the results. On the moderate and low score of ICT skills, internet knowledge and attitude towards ICT, a few suggestions could be made. Students' level of ICT skills range from low to moderate. Therefore, measures should be taken to ensure that students are given more exposure to hands-on experience, especially in school. Since not everyone can afford computers at home, school plays the role of being the main place that gives opportunities for students to use computers as frequently as possible. One of the suggested approaches to bridge the digital divide in rural areas is by giving more computer education and computer activities (Zainab and Zaitun, 2003; Zaiton and Crump, 2005 and Elmetwaly, 2010).

Furthermore, in school, teachers as educators can guide students to use computers in a productive manner, not just for recreational-type activities such as playing games and chatting on the Internet. Instead, activities involving the use of spreadsheet, databases and simple programming should be encouraged. Purposeful searching of educational websites should also be emphasized, rather than general browsing on the Internet. Teachers play an important role to develop positive attitude towards ICT including in teaching and learning. Teachers' computer acceptance is also an important 


\section{J. Social Sci., 7 (4): 619-626, 2011}

factor to the successful use of computers in education (Kumar et al., 2008a; Hassan et al., 2010).

In many rural areas in Malaysia, as in Kundang Ulu, students are lagging behind in terms of their opportunity to access ICT facilities. The percentage of students who never use computer in their life is believed to be higher in other rural areas especially in remote and secluded places. Continuous ICT literacy programme is required to improve the situation as the country is moving towards becoming a developed nation. A holistic approach to train and educate students in ICT skills is suggested by considering all important basic needs in utilising the technology. To develop an information literate society, training should move beyond teaching basic skills, but should cover technical aspects including maintaining hardware and software. ICT skills that will be useful for students in their near future for example for furthering their study and entering job market, should be emphasised, Example of such skill is multimedia application.

As in the case of Kundang Ulu, although this school is equipped with internet and wireless facility provided by MoE through the Schoolnet project, they are under-utilised. This is due to lack of computers in the school to access the internet. In addition, more than $50 \%$ of computers in the lab can no longer be used. In a well-planned strategy in ICT literacy programme, important components in developing ICT skills i.e. integrated hardware, software and furnished with internet access are considered. Other facility such as Village Internet Centre is proposed to provide community in rural areas especially students with supported cyber cafe. Evaluation, monitoring and maintenance of ICT initiatives and programmes in schools are important. The achievement of these programmes needs to be evaluated in terms of effectiveness and efficiency. The investment in such programmes requires some feedback and be justified by certain successful indicators, such as the level of ICT proficiency.

Since students showed interest toward computers, efforts in creating or instilling the right kind of attitudes toward computers among students simply means reinforcing existing positive attitudes. However, the complex nature of attitudes may require certain kind of attitude assessment to be conducted prior to computer instruction so as to determine any possible loophole in student attitudes that needs focus for improvement. Findings of such studies will determine the proper direction toward the success of technology adoption in the classroom. Additionally the instilling of positive attitude towards ICT will assist the nation to achieve its goal of an information literate society who is able to keep abreast with the latest technology development. As a final note, studying attitudes toward computer among students are critical for the successful implementation of computer and information technology in the classroom.

\section{CONCLUSION}

This study presents the results of a study to identify the problem or gaps in ICT literacy among the students in Kundang Ulu, one of the rural areas in the state of Johor. 585 participants took part in this survey with majority coming from lower secondary level. The results of this study have answered those four questions listed at the beginning of this study regarding students' skill in ICT, attitudes towards computer technologies and knowledge in Internet technologies. Our findings lead us to conclude that in general, students in rural area have moderate skill in ICT. They also have moderate attitude towards computer technologies but limited knowledge in Internet technologies. This is due to economic and geographical factors in rural areas where they live, which are limited in computer and internet facilities.

\section{ACKNOWLEDGEMENT}

This research is funded by the government under Research University Grant UKM-GUP-KRIB-18/2008 Development and Evaluation of ICT Literacy Enhancement Programme among Teachers, Administrators and Students of Sekolah Menengah Kebangsaan Tengku Temenggung Ahmad, Kundang Ulu. The researchers wish to thank all individuals who have contributed to the study.

\section{REFERENCES}

Ariffin, T.F.B.T., 2005. Gender differences in computer attitudes and skills. J. Pendidikan, 30: 75-91.

Bidgoli, H., 2004. The Internet Encyclopedia. 1st Edn., John Wiley and Sons, Hoboken, ISBN: 047122202X, pp: 880.

Burniske, R., 2001. Avaricious and envious: confessions of a computer-literate educator. Phi. Delta Kappan, 82: 524-527.

Elmetwaly, H.M.M., 2010. A System for E-Learning Processes Management. J. Comput. Sci., 6: 689692. DOI: $10.3844 /$ jcssp.2010.689.692

Hairulliza, M.J., N. Sahari N. Azan and M. Zin, 2010. Knowledge sharing towards enhancing ICT literacy. Proceedings of the International IT and Society Conference, (ITSC'10), University Community Outreach, pp: 2-6. 
Hassan, M.A., B.A. Samah, H.A.M. Shaffril and J.L. D'Silva, 2011. Socio-Demographic factors affecting attitude towards information and communication technology usage. Am. J. Applied Sci., $\quad 8$ : 547-553. DOI: 10.3844/ajassp.2011.547.553

Hindi, N.M., D. Miller and J. Wenger, 2002. Computer literacy: Implications for teaching a college-level course. J. Inform. Syst. Edu., 13: 143-151.

Idrus, R.M. and H. Atan, 2004. Closing the digital divide in Malaysia-catching them young. Malaysian Online J. Instr. Technol., 1: 33-40.

Kaur, R., K. and C.L. Siok, 2002. Tinjauan penggunaan internet di kalangan pelatih institut bahasa melayu Malaysia ke arah e-pembelajaran. Institute Bahasa Melayu Malaysia.

Kumar, N. R.C. Rose and JeffreyL. D'Silva, 2008a. Predictors of technology deployment among malaysian teachers. Am. J. Applied Sci., 5: 11271134. DOI: 10.3844/ajassp.2008.1127.1134

Kumar, N., C.R. Raduan and J.L. D'Silva, 2008b. Factors influencing the effective use of technology among Malaysian teachers. Eur. J. Soc. Sci., 6: 108-124.

Noiwan, J., T. Piyawat and A.F. Norcio, 2005. Computer attitude and computer self-efficacy: A case study of thai undergraduate students. University of Maryland Baltimore County.

Othman, M. and R. Latih, 2006. Women in computer science: no shortage here. Commun. ACM Self Manage. Sys., 49: 111-114. DOI: 10.1145/1118178.1118185

Ryan, R.M. and E.L. Deci, 2000. Intrinsic and extrinsic motivations: Classic definitions and new directions. Contemporary Edu. Psychol., 25: 54-67. DOI: 10.1006/ceps.1999.1020

Schweinle, A., D.K. Meyer and J.C. Turner, 2006. Striking the right balance: students' motivation and affect in elementary mathematics. J. Edu. Rese., 99: 271-294.
Teck, S.H. and Y.L. Lai, 2011. An empirical analysis of malaysian pre-university students' ICT competency gender differences. Inter. J. Network Mobile Technol., 2: 15-29.

Tella, A. and S.M. Mutula, 2008. Gender differences in computer literacy among undergraduate students at the University of Botswana: Implications for library use. Malaysian. J. Library Inform. Sci., 13: 59-76.

Vansteenkiste, M., J. Simons, W. Lens, K.M. Sheldon and E.L. Deci, 2004. Motivating learning, performance and persistence: The synergistic effects of intrinsic goal contents and autonomysupportive contexts. J. Per. Social Psychol., 87: 246-260. PMID: 15301630

Yasin, N.M., 2002. Digital divide in education: The Malaysian experience. University of Malaya.

Zainab, A.N.A.D. and A.B. Zaitun, 2003 The impact of IT on higher education for Malaysia. University of Malaya.

Zaiton, A.B. and B. Crump, 2005. Overcoming the digital divide-a proposal on how institutions of higher education can play a role. Malaysian Online J. Instructional Technol., 2: 1-11.

Zin, N.A.M., H.B. Zaman, H.M. Judi, N.A. Mokti and H.M. Amin et al., 2000. Gender differences in computer literacy level among undergraduate students in universiti kebangsaan Malaysia. Electronic J. Information Syst. Developing Countries.

Zuhari, S.Z.A., K.K. Salayang and A.A. Rahman, 2009. Technology Task Pelajar Kolej Komuniti Luar Bandar. In: Universiti Tun Hussein Onn Malaysia. 